\title{
Haematology and Growth Study of Albino Rats Fed Varying Inclusions of Cooked Canavalia Plagiosperma Piper Seed Meal Based-Diets
}

\author{
Alagbaoso S.O ${ }^{1, *}$, Nwosu J.N. ${ }^{1}$, Njoku N.E. ${ }^{1}$, Okoye E.C. ${ }^{2}$, Eluchie C.N. ${ }^{1}$, Agunwa I.M ${ }^{1}$ \\ ${ }^{1}$ Department of Food Science and Technology, Federal University of Technology, Owerri, Imo State \\ ${ }^{2}$ Department of Food Science and Technology, University of Nigeria, Nsukka \\ *Corresponding author: alagbaososerah@gmail.com
}

\begin{abstract}
The haematology and growth study of albino rats fed varying inclusions of cooked canavalia plagiosperma piper seed meal based diets was studied. Raw seeds of Canavalia plagiosperma (Oblique-seeded Jack bean) were cooked (50 minutes). Toxicity study was carried out on the seed during which albino rats were used. Haematological studies were carried out on the blood samples of the albino rats as well as the growth performances of the rats fed the prepared diets were also analyzed. The result of the proximate composition of diets showed that ash, moisture, fat and total energy showed a significant increasing effect $(\mathrm{P} \leq 0.05)$ as the concentration of the processed sample increases in the feed mix, whereas, a significant decreasing effect $(\mathrm{P} \geq 0.05)$ was observed on protein, carbohydrate and crude fibre as the concentration of the cooked seed increases in the feed mix. Protein efficiency ratio (PER) study showed that 75:25 blends of cooked - to - control were considered as intermediate quality seed protein whereas 50:50, 75:25 blends of cooked - to - control feed mix as well as the control diet posses' protein with good quality. The Haematological studies showed specific and selective effect on some albino rats' blood samples which has the ability to cause thromboembolism, hyposplenism and thrombocytosis with possible vascular accidents at higher ratio.
\end{abstract}

Keywords: canavalia plagiosperma piper, heamatological parameters, cooking, proximate, protein efficiency ratio

Cite This Article: Alagbaoso S.O, Nwosu J.N., Njoku N.E., Okoye E.C., Eluchie C.N., and Agunwa I.M, "Haematology and Growth Study of Albino Rats Fed Varying Inclusions of Cooked Canavalia Plagiosperma Piper Seed Meal Based-Diets.” Journal of Food and Nutrition Research, vol. 5, no. 9 (2017): 649-658. doi: 10.12691/jfnr-5-9-4.

\section{Introduction}

Oblique-seeded jackbean or giant bean (Canavalia plagiosperma piper) is also called Riesenbohene in German, Pellarde losgentills or Promo gigante in Spanish, and "ukpo Ghana" in the Eastern part of Nigeria. Canavalia plagiosperma belongs to the family of leguminosae known as fabaceae and subfamily of papilionoideae. The genus comprises of approximately 70-75 species of tropical origin. Canavalia plagiosperma piper is a hybrid of Canavalia ensiformis (Jackbean) and Canavalia gliadiata (sword bean) [1]. Canavalia plagiosperma is a high forage and seed yielding tropical legume with high energy and protein content and quality for Nigerian livestock industry [2]. Initial effort at determining the nutritional composition of the raw unprocessed dry seed of C. plagiosperma suggests that it has crude protein content of $35.53 \%$ which could be used to fortify cereal based diets .Recent research by Esonu et al., [3] showed that raw seed of Canavalia plagiosperma contains crude protein $36.11 \%$, moisture $19.35 \%$, crude fibre $5.12 \%$, ash $1.80 \%$, carbohydrate $51.46 \%$, crude fat
$5.48 \%$, dry matter $80.65 \%$. Also the nutritive and protein quality of the seed as shown by some studies seems to be similar to that of most of the edible legume grains and hence, they are advocated to be a good source for extending protein sources [4]. The use of Canavalia plagiosperma (raw) as a high protein food and forage crop for some countries like Mexico, Brasil and Central America has been documented [5]. In "Ikwuano" Umuahia in Abia State of Nigeria, the seed is used as soup thickner, but it was reported that the thickening effect is low which reduced its usage as a soup thickner [6]. Also, the young pods and immature seeds of canavalia plagiosperma are used generally as vegetables. The immature pods are made into a dish directly or often boiled with water; also the immature seeds are often consumed as curries and as a substitute for mashed potatoes [6]. Despite the desirable nutritive features of C. plagiosperma seed, it is not extensively utilized as food for man and /or feed for ruminants mainly due to the presence of certain anti-nutritional compounds [6,7].

Some of the problems associated with Canavalia plagiosperma is unavailability due to poor utilization and unfamiliarity. There are also uncertainties concerning the appropriateness of heat treatment and the degree/timing of 
such treatments. Canavalia plagiosperma has been noted by Esonu [6], to contain some anti-nutrients. Also, Odoemelam, [5] and Moreina et al. [4], documented that the raw seed contains $35.53 \%$ of crude protein. Despite the high protein content of the seed, yet it is not generally utilized as food or in food formulations for human consumption. This could be as a result of anti-nutrients contained by the seed [4].

Cooking (moist heat) in our previous work [8] has been shown to reduce toxic substances in Canavalia plagiosperma seed, but there is no information on its possible influence on the haematology and growth after consumption. This study aimed to investigate the haematology and growth study of albino rats fed varying inclusions of cooked canavalia plagiosperma piper seed meal based- diets.

\section{Materials and Chemicals}

The fresh seeds of Canavalia plagiosperma for this study were obtained from Ikwuano Umuahia in Abia State of Nigeria.

All equipment and chemicals used were available at Reliable research laboratory services Umuahia, Abia state; National Root Crops Research Institute (NRCRI)
Umudike; and Federal University of Technology (FUTO), Owerri, Imo State. All the chemicals used were of analytical grade.

Sample preparation: The healthy seeds of $C$. plagiosperma were dehulled by parboiling at the temperature of $100^{\circ} \mathrm{C}$ for 5 minutes to ease decoating of the seeds, after which the coats were removed manually. Then, the dehulled /decoated seeds were dried using a moisture extraction oven (Gallenkamp hot box oven) at the temperature of $60^{\circ} \mathrm{C}$ for 3 hours.

The decoated seeds were divided into 2 batches. One batch was further divided into 3 portions, the 3 portions were cooked at the temperature of $100^{\circ} \mathrm{C}$ but at different cooking times of 30,40, and 50 minutes respectively in a seed to water ratio of 1:10 (w/v), The cooked seeds were rinsed with distilled water and then dried using a moisture extraction oven (Gallenkamp hot box oven) at $60^{\circ} \mathrm{C}$ for 3 hours. The processed dried seeds were milled and kept in an air tight container to avoid moisture reabsorption. Samples were evaluated for anti-nutritional factors and proximate composition (a separate paper), the sample with best/least anti-nutritional factors was used for feed formulations and feeding trials. The raw seeds were also dehulled, milled and stored in an air tight container which was analyzed as control.

\section{Raw undehulled Canavalia plagiosperma piper}
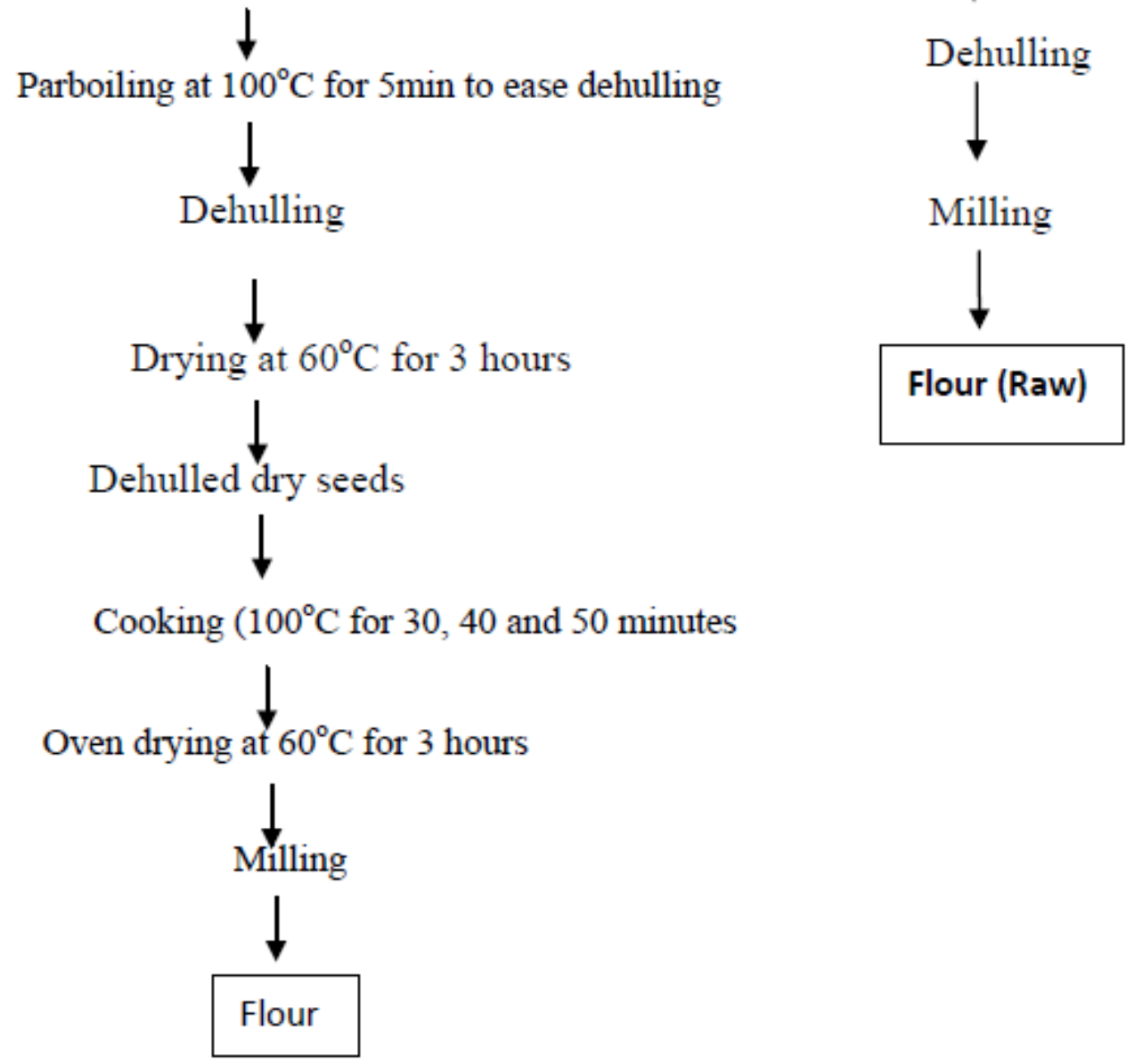


\section{Analytical Methods}

Proximate analysis: The proximate analysis was carried out according to the methods outlined by the Association of Official Analytical Chemists [9].

\section{Toxicity Study}

\subsection{Albino Rats for the Study}

Forty five (25) numbers of 21 days old male albino rats (Rattus nowegicus) purchased from Emii vertinary farm at 120 Royce road, Owerri ,Imo state were used for the feeding trials, and were randomly divided into nine groups (5 groups of 5 rats each). The rats were housed individually in metal cages placed under a well ventilated laboratory with temperature (27 \pm 2$)$, Relative humidity (85\%) and an alternate 12 hour natural light/ 12 hour dark cycles. The animals were allowed to acclimatize for 7 days at the venue of the experiment before taking the initial weight of the albino rats (Rattus nowegicus).

The basal diet (control) contains protein $20 \%$, corn oil $8 \%$, salt mixture ${ }^{\mathrm{a}} 5 \%$,vitamin/trace minerals premix ${ }^{\mathrm{b}} 1 \%$, Non nutritive fiber (cellulose) 1\%,fish meal 3\%, bone meal $3 \%$ and maize meal $60 \%$.

a \& b: prepa red by F. Hoffman -La Roche and company Ag. Switzerland based on formulation for laboratory animals. a: Salt mixture composition (content $/ \mathrm{kg}$ ), calcium 6g; chloride 5g; copper $10 \mathrm{mg}$; iodine $0.2 \mathrm{mg}$; Iron 100mg; magnesium 2.0g; manganese $75 \mathrm{mg}$; phosphorus 5g; potassium 5.0g; sodium 5.0g; zinc $18 \mathrm{mg}$.

b: Vitamin/trace minerals premix contained international units, (IU or $\mathrm{Mg}$ or $\mu \mathrm{g}$ per $\mathrm{kg}$ of diet): vitamin A 7,000 (I.U);Vitamin D 300 (I.U); Vitamin E 60 (I.U);Vitamin K 2.9 mg; Thiamin $\mathrm{HCl} 4.0 \mathrm{mg}$; Riboflavin $5 \mathrm{mg}$; pyridoxine $\mathrm{HCl} 6 \mathrm{mg}$; Niacin $10 \mathrm{mg}$; pantothenic acid 12.0 mg; Cyanocobalamin $\left(B_{12}\right) 5.0 \mu$ g.

\subsection{Experimental Diets/Treatments}

The albino rats were randomly divided into 5 groups (A, B, C, D, E) consisting of 5 rats each.

Group A (control) was fed with $100 \%$ of basal rat feed and water for 21 days for haematological analysis and for extra one week for Protein efficiency ratio (PER) study.

Groups B, C, D and E were fed with the samples cooked at $100^{\circ} \mathrm{C}$ for 35 minutes autoclaved samples were Incorporated into the basal feed at $25 \%, 50 \%, 75 \%$ or $100 \%$ level. Water was given for 21 days for haematological analysis and for extra one week for PER study.

\subsection{Growth Performance Study}

The growth Performance was studied with the method described by Pugalenthi et al., [9].

Feed Intake (FI)

This is the sum of the quantity of feed consumed by the rats for 28 days

Body Weight Gain (BWG)

$$
\text { BWG }=\frac{\text { Initial weight gain }- \text { Final weight gain }}{\text { Final weight gain }} \times 100(1)
$$

Feed Efficiency Ratio (FER)

$$
\mathrm{FER}=\frac{\text { Body weight gain }}{\text { feed } \text { intake }}
$$

Protein Efficiency Ratio (PER)

$$
\mathrm{PER}=\frac{\text { Body weight gain }}{\text { protein consumed }}
$$

\subsection{General Observations}

The experimental animals (albino rats) were observed twice daily for mortality and morbidity. Any abnormality in terms of behavioral and physical changes such as eyes, skin, posture, fur, and response to handling were observed. The time it started and how long it lasted, if any, were also recorded. The weight of all the experimental groups and the control were recorded weekly, beginning from a day before feeding them with the experimental diet (initial body weight).The final body weights were measured a day to the end of the experiment $\left(20^{\text {th }}\right.$ day), The quantity of feed consumed by each rat was recorded daily.

\subsection{Haematological Analysis}

This was done by the method described by Akinnawo et al., [10]. At the end of experiment, the experimental albino rats were anaesthetized with chloroform and blood was collected by cardiac puncture and two (2) $\mathrm{ml}$ of blood from each rat was collected into sample bottles containing disodium EDTA and used to determine the haematological parameters.

\subsection{Determination of Haematological Parameters}

\subsubsection{Determination of White Blood Cell Count (WBC)}

The counting of total white blood cells was done using a diluting fluid (Turks fluid) in a ratio of 1:20 and then counted with an improved Neubauer counting chamber under a light microscope (mcArthur microscope) using a x10 objective in an area of 4 sqmm. The cells appeared as small black dots. The number was thus calculated:

$$
\begin{aligned}
& \text { White blood cells } \\
& =\frac{\text { Cells counted } \times \text { blood dilution } \times \text { chamber depth }}{\text { Area of chamber counted }} .
\end{aligned}
$$

\subsubsection{Determination of Red Blood Cell Count (RBC)}

The red blood cells (RBC) count was done using the conventional method of Dacie and Lewis (2001). Blood was diluted to 1:200 with Hayem's fluid which preserved the corpuscles and then counted with an improved Neubauer counted chamber under a light microscope (Mc Arthur Microscope) using a x40 objective in an area of 15 sqmm. Their characteristic pink-red colour was used for their identification.

The number was then calculated thus

$$
=\frac{\text { Cells counted } \times \text { blood dilution } \times \text { chamber depth }}{\text { Area of chamber counted }} \text {. }
$$




\subsubsection{Determination of Packed Cell Volume (PCV).}

The packed cell volume (PVC) was done using the macrohaematocrit method (Dacie and Lewis, 2001). The blood sample was added to a bottle containing heparin $(0.1 \mathrm{mg} / \mathrm{ml}$ of blood). The haematocrit tube was filled to $100 \mathrm{~mm}$ with a capillary pipette and it was centrifuged at $3,000 \mathrm{rpm}$ for 30 minutes. The height of the red blood cells was read and the results were expressed as a percentage of packed cell volume.

\subsubsection{Determination of Platelets}

The platelets were determination by diluting the blood in one percent (1\%) ammonium oxalate which haemolysed the red blood cells. The platelets were then counted in a definite area using the rulings of an improved Neubaucer counting chamber. Their characteristic Mauve-pink colour was used in their identificat ion.

\subsubsection{Determination of Haemoglobin Estimation}

The conventional method (Sahli's haemoglobinometer) was employed for the estimation of haemoglobin $(\mathrm{Hb})$ content of the blood. Using the Sahli haemoglobinometer, the colour of the test solution was filled to $20 \mathrm{ml}$ mark with $10 \mathrm{~N}$ hydrochloric acid. $0.02 \mathrm{ml}$ of blood was added and the content of the test tube was mixed with glass rod. It was left for 5 minutes (for the haemoglobin to be changed into acid haematin). More acid was thereafter added and the mixture was stirred until the colour of the test solution matched that of the coloured glass standard. The level of the fluid in the tube was read and the haemoglobin content was expressed as a percentage.

\subsubsection{Determination of Leucocytes (Differential White Blood Cell Count)}

The differential white blood cell count (Neutrophils, Lymphocytes, monocytes, Eosinophils and Basophils) was done by making a thin film of blood on a smooth edged slide. It was allowed to dry on a bench protected from dust, ants, flies, and other insects. The blood film was fixed a covered staining jar of methyl alcohol for 3 minutes. Ten (10) $\mathrm{ml}$ of May Grunwald Stain (mixture of $5 \mathrm{~g}$ of May Grunwald powder and 1 litre of methanol) and $10 \mathrm{ml}$ of buffered water $(\mathrm{pH}$ 6.8) was mixed thoroughly and the smear was covered with the dilute May Grunwald stain for 3 minutes. The stain was tipped off and replaced with diluted Giemsa's stain (5\%) for 9 minutes. The stain was washed off with buffered water $(\mathrm{Ph}$ 6.8) and clean water was dropped on the slide which was allowed to stay for 30 seconds. The water was tipped off and the slide was allowed to dry. It was then examined microscopically (McArthur microscope) for the identification of Neutrophils (cytoplasm stained pink with small mauve granules), Eosinophils (cytoplasm stained pink with large red granules), Basophils (cytoplasm contained dark mauve-blue granules) Monocytes (cytoplasm stained dull grey-blue) while lymphocytes (cytoplasm stained blue).

\subsubsection{Determination of Mean Corpuscular haemoglobin (MCH), Means Corpuscular Haemoglobin Concentration (MCHC), and Mean Corpuscular Volume (MCV) Determination}

The mean corpuscular haemoglobin (MCH), mean corpuscular haemoglobin concentrated (MCHC) and mean corpuscular volume (MCV) were calculated from the values obtained from red blood cells (RBC), packed cell volume (PCV) and Haemoglobin (Hb) content. They were calculated thus:

$$
\begin{aligned}
& \text { Mean corpuscular haemoglobin }(\mathrm{MCH}) \\
& =\frac{\text { Haemoglobin content }}{\text { Red blood cell counted }} \times \frac{10}{1} .
\end{aligned}
$$

Mean corpuscular Haemoglobin concentration (MCHC)

$$
\begin{gathered}
=\frac{\text { Haemoglobin content }}{\text { Packed cell volume }} \times \frac{100}{1} \\
\text { Mean corpuscular volume }(\mathrm{MCV}) \\
=\frac{\text { Packed cell volume }}{\text { Red blood cell count }} \times \frac{10}{1} .
\end{gathered}
$$

\subsection{Data Analysis}

The results obtained from the data were subjected to Analysis of variance (ANOVA) according to Onuh and Igwemma [10] and SAS (1999). Significant means at $\mathrm{p} \leq 0.05$ were separated using Fisher's least significant difference (LSD) test [10].

\section{Results and Discussion}

\subsection{Proximate Composition of the Diets Fed to Albino Rats}

The proximate composition of the diets fed to the rats during the feeding trials was shown in Table 1 . There was a significant difference $(\mathrm{P} \leq 0.05)$ in moisture content among the test diets and also the control diets; Moisture content of any food is an index of its water activity and is used as a measure of stability and susceptibility to microbial contamination [11], The moisture content of the diets indicates that the diets can be processed and kept for sometime without microbial spoilage and deterioration in quality.

The protein content of the cooked seed inclusive diets was significantly lower than that of the control diet. This may likely be as a result of the blend ratio; as the control sample reduces, the protein content reduces. This may be associated with the increased body weight gain and better protein efficiency ratio (PER) (Table 2) noticed in the rats fed with 75:25, 50:50 control to cooked sample inclusive diets when compared with the control diets. It is generally known that any food that provides more than $12 \%$ of their caloric value from protein is considered to be a good source of protein. Thus, the diets contain sufficient amount of protein required by the rats, thus, they are good source of protein.

The ash content of the cooked sample inclusive diets are higher than that of the control diet. Ash represents the mineral matter left after food material is burnt in oxygen and it is used as a tool to measure the mineral content in any sample [12]. The cooked C. plagiosperma piper inclusive diets had moderately high value of ash (2.51- 2.71\%), which indicates that the seed has good mineral content, hence, can serve as a viable tool for nutritional evaluation [13]. 
Table 1. Proximate composition of the diets fed to Albino Rats

\begin{tabular}{lcccccc}
\hline Parameters & Diet 1 & Diet 2 & Diet 3 & Diet 4 & Diet 5 & LSD \\
\hline Moisture (\%) & $3.08^{\mathrm{I}} \pm 0.06$ & $6.07^{\mathrm{g}} \pm 0.03$ & $6.07^{\mathrm{d}} \pm 0.02$ & $8.12^{\mathrm{C}} \pm 0.01$ & $8.67^{\mathrm{a}} \pm 0.02$ & 0.09 \\
CRUDE PROTEIN (\%) & $35.32^{\mathrm{a}} \pm 0.06$ & $31.47^{\mathrm{d}} \pm 0.06$ & $29.71^{\mathrm{g}} \pm 0.02$ & $28.20^{\mathrm{C}} \pm 0.02$ & $28.75^{\mathrm{I}} \pm 0.01$ & 0.08 \\
ASH (\%) & $2.53^{\mathrm{efg}} \pm 0.01$ & $2.51^{\mathrm{fg}} \pm 0.02$ & $2.71^{\mathrm{g}} \pm 0.06$ & $2.55^{\mathrm{ef}} \pm 0.00$ & $2.57^{\mathrm{ed}} \pm 0.02$ & 0.05 \\
Crude fat (\%) & $0.66^{\mathrm{I}} \pm 0.01$ & $1.30^{\mathrm{h}} \pm 0.11$ & $3.37^{\mathrm{f}} \pm 0.05$ & $5.85^{\mathrm{d}} \pm 0.01$ & $6.76^{\mathrm{c}} \pm 0.02$ & 0.08 \\
Crude Fibre (\%) & $3.02^{\mathrm{a}} \pm 0.02$ & $2.73^{\mathrm{C}} \pm 0.01$ & $1.67^{\mathrm{d}} \pm 0.03$ & $1.09^{\mathrm{C}} \pm 0.00$ & $0.06^{\mathrm{g}} \pm 0.01$ & 0.07 \\
CHO (\%) & $55.45^{\mathrm{b}} \pm 0.01$ & $55.95^{\mathrm{a}} \pm 0.01$ & $54.97^{\mathrm{C}} \pm 0.01$ & $52.96^{\mathrm{e}} \pm 0.03$ & $52.57^{\mathrm{g}} \pm 0.03$ & 0.05 \\
Total energy Value Kj/g & $1531.98^{\mathrm{f}} \pm 0.64$ & $1500.70^{\mathrm{h}} \pm 0.23$ & $1533.06^{\mathrm{f}} \pm 0.02$ & $1588.18^{\mathrm{d}} \pm 0.23$ & $1604.60^{\mathrm{C}} \pm 0.11$ & 1.71 \\
\hline
\end{tabular}

Note $=$ Means with different superscripts in the same column are significantly at $\mathrm{P} \leq 0.05 . \mathrm{LSD}=$ Least Significant difference

Diet $1=$ Standard rat feed (Control)

Diet $2=25: 75$ cooked sample to standard rat feed mix

Diet $3=50: 50$ cooked sample to standard rat feed mix.

Diet 4 $=75: 25$ Cooked sample to standard rat feed mix

Diet 5= 100:0 cooked sample.

The fat content of the blends increases as the concentration of the cooked sample increases in the feed mix. There was significant difference between the test samples and the control, and also among the test samples.

The crude fiber content of the diets decreased as the concentration of sample increased in the feed mix. This proved that the seed contain low crude fiber. Fibre has some physiological effect in the gastrointestinal track [14] and low fibre in diet is undesirable as it may cause constipation. This implies that the low fibre content reported in the cooked sample inclusive diets suggests that rats consuming these diets may suffer constipation.

The carbohydrate content of the diets is significantly different from each other. Diets 5 (100\% cooked) had the lowest carbohydrate content; this may be attributed to the weakness observed in the rats fed with the diet which lead to their death. The total energy value of the diets is significantly different. Diet 5 had the highest total energy value; this may be attributed to the fact that it has the highest fat content. Energy is dependent on fat, protein and carbohydrate since they are computed from them.

\subsection{Feed Intake and Weight Gain}

The albino rats feed intake levels are shown in Figure 1 to Figure 4 while their weekly weight gain record is shown in Figure 5. From Figure 1 - Figure 4, groups of Albino rats fed with $75 \%$ and $100 \%$ of cooked Canavalia plagiosperma seed sample to standard rat feed respectively showed a decreased feed consumption. This may be attributed to the non palatability of the feed mix since the Canavalia plagiosperma seed sample is at relatively high concentrations in the mix. Group fed with 25\% and 50\% cooked Canavalia plagiosperma seed sample to standard rat feed respectively were very comparable to the control group that was fed the normal standard rat feed. This may be as a result of the lower ratios of the Canavalia plagiosperma piper seed sample which possibly did not adversely affect the palatability of the feed mix. Group rats fed $100 \%$ cooked seed had reduced weight from the week I while other test groups displayed body weight gains similar to those fed normal control group A (Figure 1 - Figure 4). The graphical representations of weekly feed intake of albino rats fed with the various feed mixes are as follows;

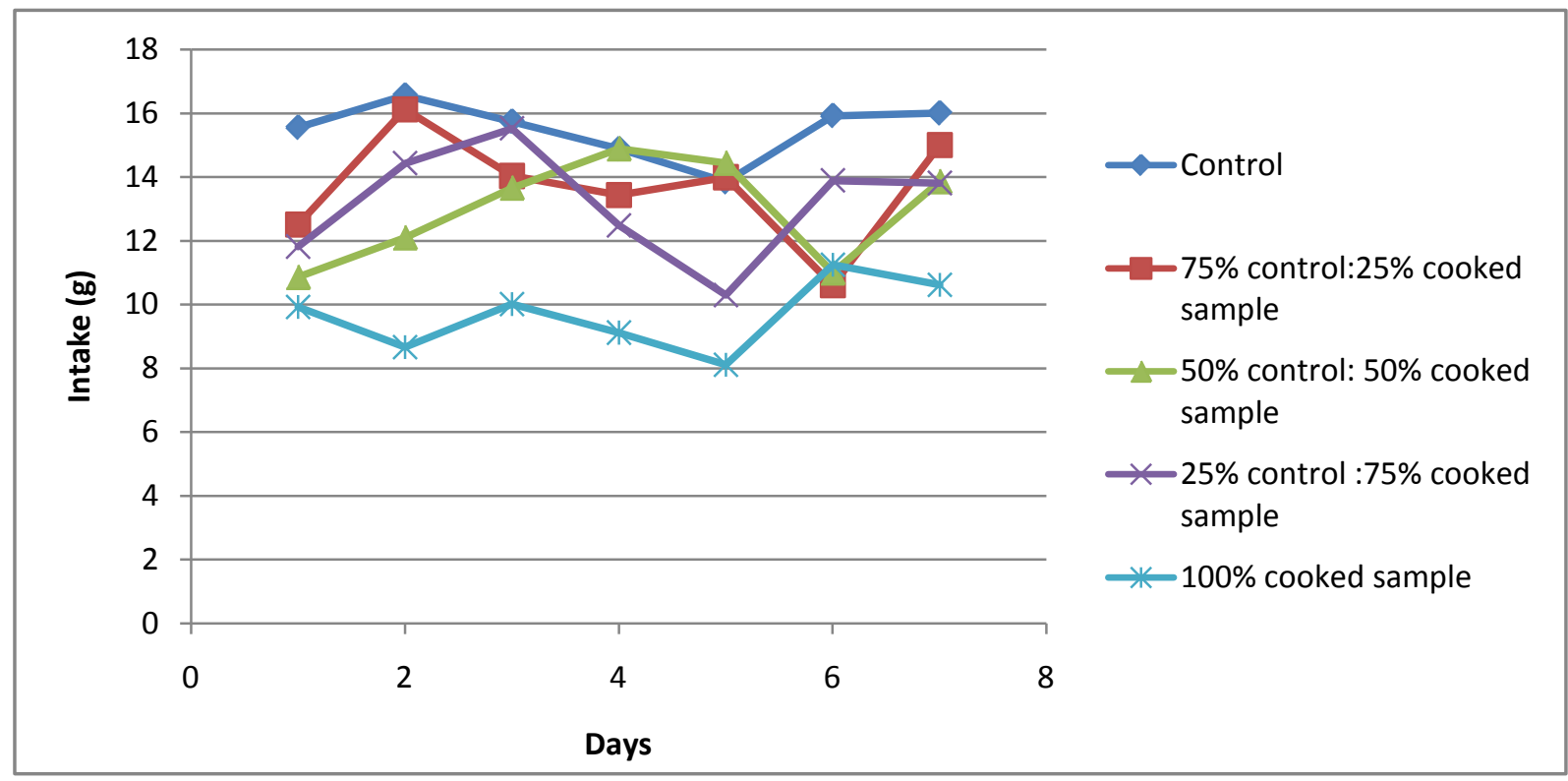

Figure 1. Daily feed intake for week 1 for rats fed with varying levels of cooked Canavalia plagiosperma and the control 


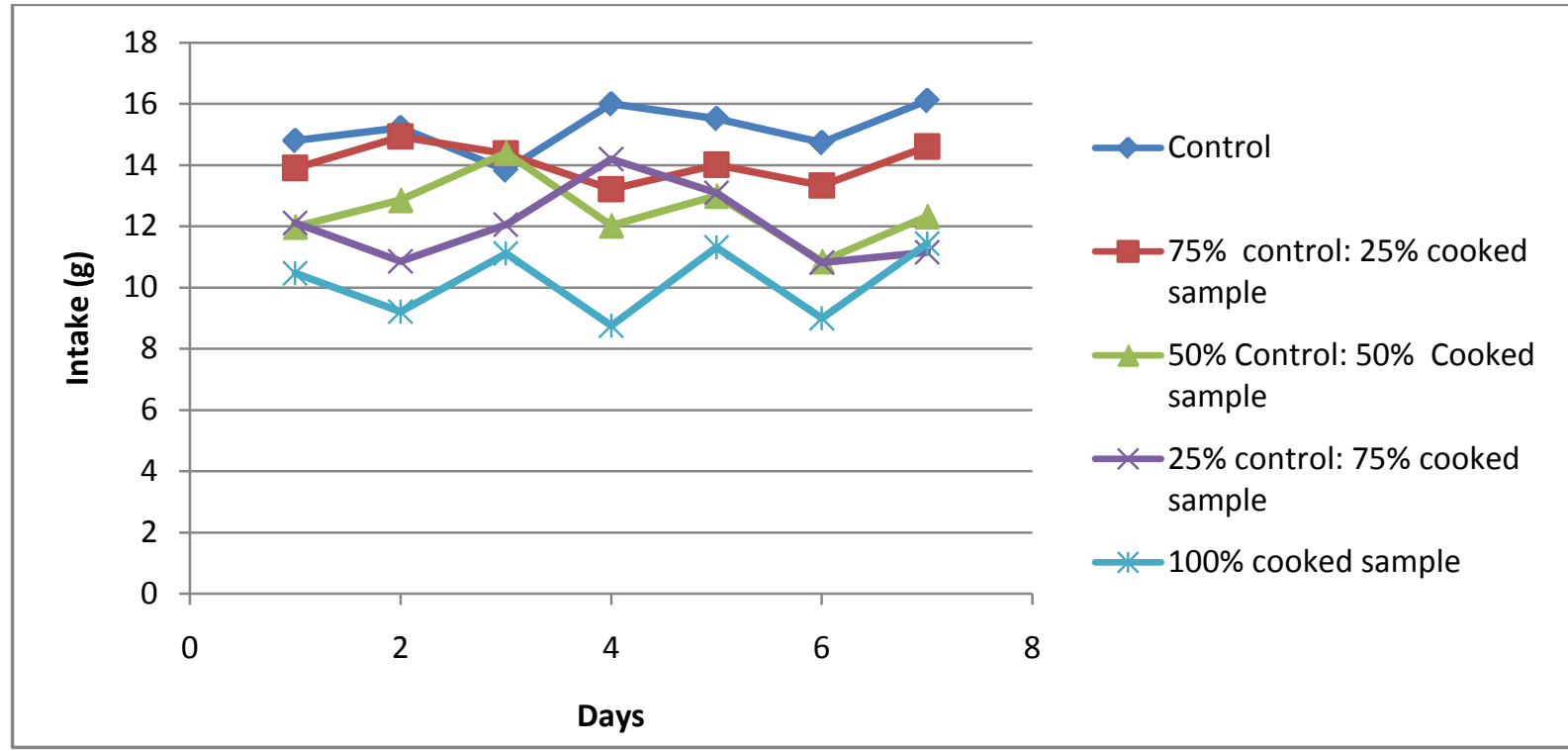

Figure 2. Daily feed intake for week 2 for rats fed with varying levels of cooked Canavalia plagiosperma and the control.

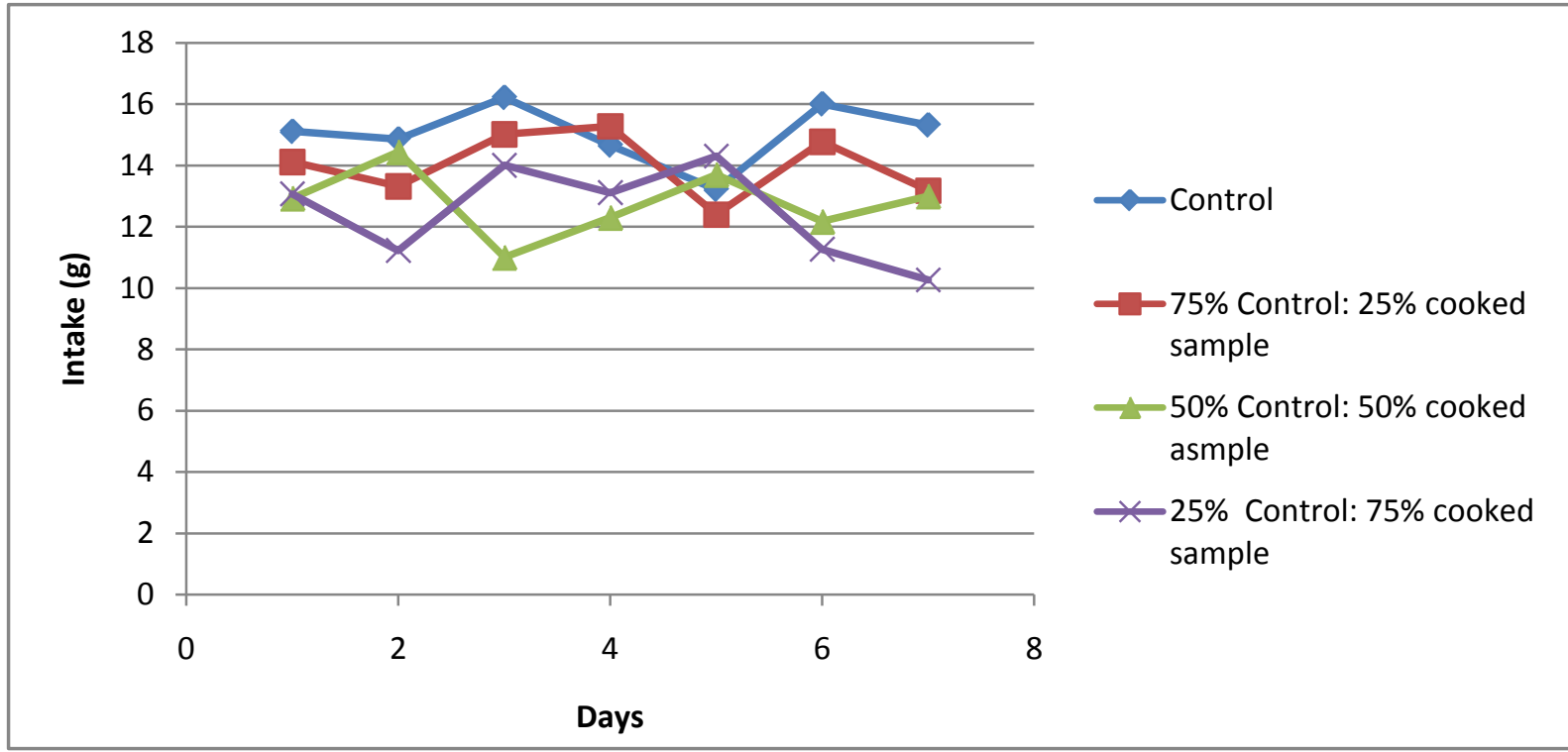

Figure 3. Daily feed intake for week 3 for rats fed with varying levels of cooked Canavalia plagiosperma and the control

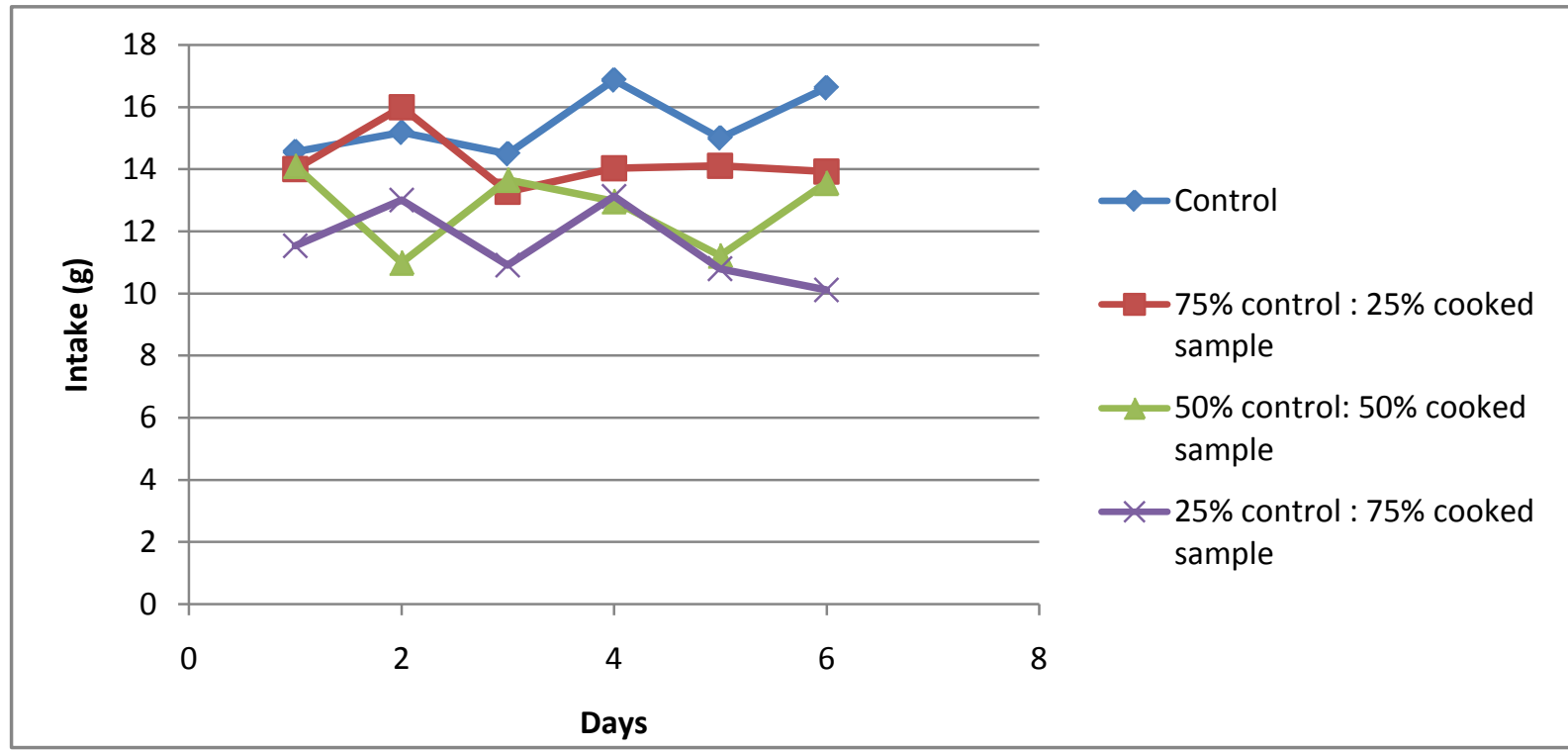

Figure 4. Daily feed intake for week 4 for rats fed with varying levels of Cooked Canavalia plagiosperma and the control 


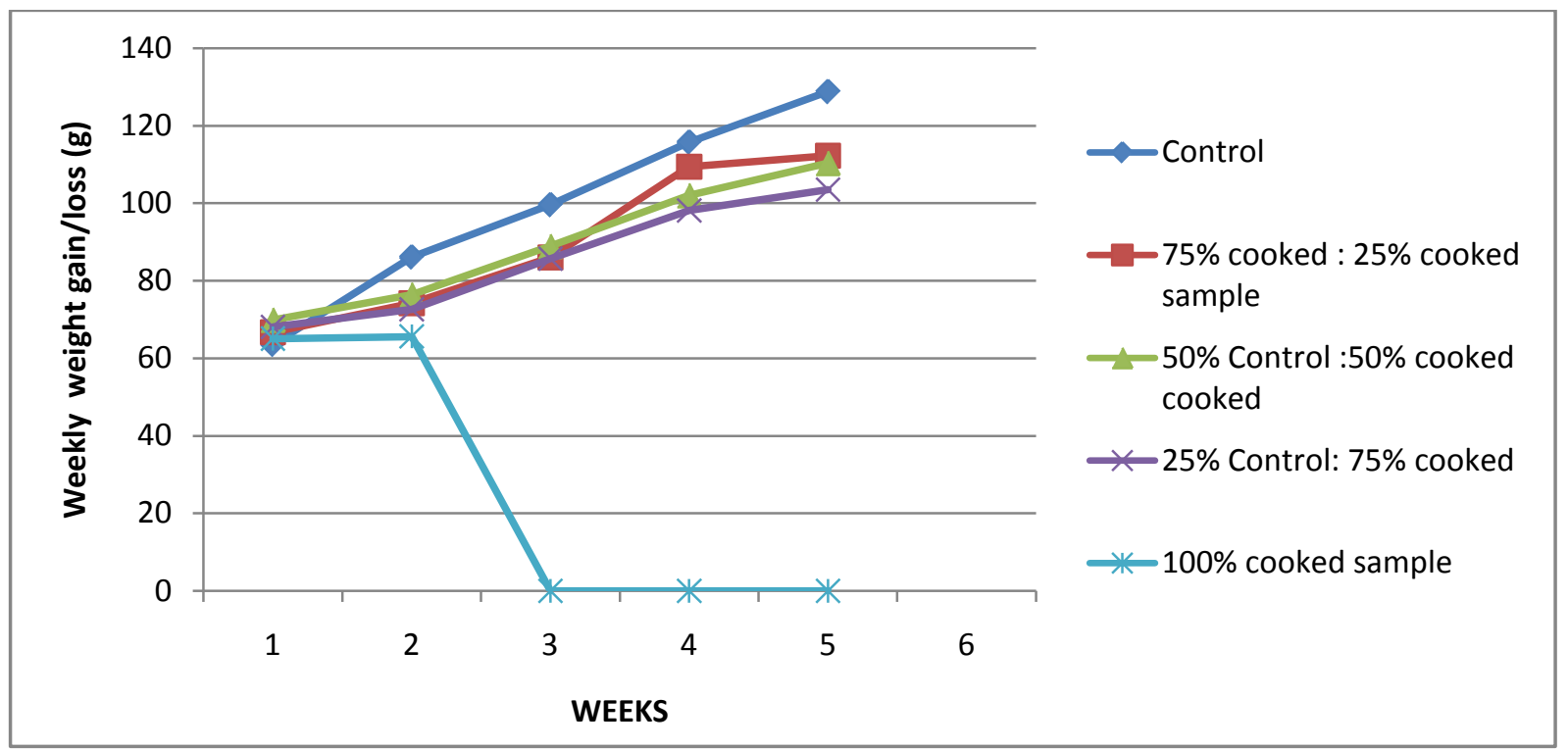

Figure 5. Weekly mean weight gain/ loss of rats fed with diets containing varying levels of cooked Canavalia plagiosperma and the control

The general observations made on the albino rats: Albino rats in groups fed $100 \%$ cooked seeds died after 14 days of the feeding trial (Figure 5). The rats developed a very dull behavior, a fur arrangement that revealed some very minute uncovered straight line skin areas with a dim, dull and partially closed eyes were observed a day before the death of the albino rats. This may be attributed to the fact that the heat treatments given to the seed did not totally eliminate the anti-nutrients; hence their accumulation could lead to the above observations. It may also be as a result of low quantity of feed they consumed, which indicates that the rats were starved to death. The result of haematological analysis revealed that lymphocytes increased at higher concentration of the seed in the feed mix. When lymphocyte increased above normal limit causes inflammation of the kidney and liver, which may be what caused the observations made above. Also, packed cell volume (PCV) and haemoglobin ( $\mathrm{Hb})$ increases as the concentration of the Canavalia Plaagiosperma increases in the feed mix, the PCV and $\mathrm{Hb}$ may have increased beyond normal limits. A high $\mathrm{Hb}$ level in the blood causes thromboembolism. While high level of PCV causes venous thromboembolism /vascular accidents (heart failure/block, renal failure, Ishaemi stroke, possible retinopathy) $[13,15]$. Thus, it is likely that the mortality recorded may have resulted from the conditions mentioned above. This suggests that the blends of Canavalia plagiosperma should be consumed since the $100 \%$ feed is likely to cause the above health problems and eventually cause death.

Growth performance of the experimental animals and protein efficiency ratio (per) of processed seeds of canavalia plagiosperma.

\subsection{Growth Performance of the Animals}

The results of the growth performance are shown in Table 2.

The feed intake (FI) g/28days values of all the test groups were significantly lower than that of the control group animals. The animals fed with 25:75 control and cooked Canavalia Plagiosperma seed sample feed mix gave the lowest FI value (344.36g/28days). The significantly lower FI value found in rats fed with 25:75 control to cooked diet were probably due to the difference between the diets in protein quality which reduced its palatability. The animals in group 4 showed lowest body weight gain (BWG) value (51.95g/28days), when compared to the group 1 (control) which had BWG value of $102.42 \mathrm{~g} / 28$ days.

Table 2. Growth Performance of the Experimental Animals and Protein Efficiency Ratio (PER) of Cooked Seeds of Canavalia Plagiosperma

\begin{tabular}{|c|c|c|c|c|}
\hline \multirow[b]{2}{*}{ Experimental Animals } & \multicolumn{4}{|c|}{ Growth Performance of the Experimental Animals } \\
\hline & Feed Intake (FI) g/28days & $\begin{array}{c}\text { Body Weight Gain } \\
\text { (BWA), g/28days }\end{array}$ & $\begin{array}{c}\text { Feed Efficiency Ratio } \\
\text { (FER) }\end{array}$ & $\begin{array}{c}\text { Protein Efficiency } \\
\text { Ratio (PER) } \\
\end{array}$ \\
\hline Control group animals ${ }^{1}$ & $428.09^{\mathrm{a}} \pm 0.06$ & $102.42^{\mathrm{a}} \pm 1.00$ & $0.24^{\mathrm{d}} \pm 0.00$ & $2.83^{\mathrm{b}} \pm 0.12$ \\
\hline Test group animals ${ }^{2}$ & $392.31^{\mathrm{C}} \pm 0.00$ & $68.16^{\mathrm{c}} \pm 0.04$ & $0.17^{\mathrm{Cb}} \pm 0.01$ & $2.19^{\mathrm{b}} \pm 0.05$ \\
\hline Test group animals ${ }^{3}$ & $356.83^{\mathrm{F}} \pm 0.01$ & $57.83^{d} \pm 0.02$ & $0.17^{\mathrm{cb}} \pm 0.01$ & $1.94^{\mathrm{c}} \pm 0.01$ \\
\hline Test group animals ${ }^{4}$ & $344.36^{\mathrm{g}} \pm 0.02$ & $51.95^{\mathrm{f}} \pm 0.01$ & $0.16^{\mathrm{C}} \pm 0.01$ & $1.81^{\mathrm{c}} \pm 0.00$ \\
\hline LSD & 0.39 & 0.66 & 0.02 & 0.15 \\
\hline
\end{tabular}

NOTE: Means with different superscripts along the same column are significantly different at $\mathrm{p} \leq 0.05$

LSD: Least significant difference

${ }^{1}$ Fed with $100 \%$ control

${ }^{2}$ Fed with $25 * *$

${ }^{3}$ Fed with $50 * *$

**\% replacement with cooked sample. 
The BWG value of the test groups and the control are significantly different from each other. The body weight gain (BWG) of the rats might be associated with feed intake going by the corresponding trend in weight increase with intake (g) per day. The poor performance in weight gain of rats fed diets 4 and the death of rats fed 100\% cooked sample might be likely due to low quantity of feed they consumed.

Protein efficiency ratio (PER): The Protein efficiency ratio (PER) value of $25.75 \%$ blend of control and cooked seed of Canavalia Plagiosperma feed mix gave the PER values of 1.81 (Table 2) which is lower when compared with the PER value (2.83) of the control diet. This might be due to the poor quality of proteins of the Canavalia plagiosperma seeds. However, the PER value of 75:25 of cooked (1.81) and control feed were higher than that of faba beans (0.32) [16] but lower than that of vegetable peas (2.17) [17].

Among the cooked sample inclusive diets, There was significant $(\mathrm{P}<0.05)$ improvement of $\mathrm{PER}$ value $(1.81$ to 2.19) of Canavalia Plagiosperma seeds. The results observed from the present study showed that the higher the feed intake (FI), the higher the PER values obtained, which coincided with an earlier report given by Pugalenthi et al., [18] in which he pointed out that the PER determination depends upon feed consumption.

The low PER value of diets blended with cooked and control in the ratios $75 \%$ cooked to $25 \%$ control, $50 \%$ cooked to $50 \%$ control, $25 \%$ cooked to $75 \%$ control giving PER of (1.81, 1.94 and 2.19) respectively compared to the PER value of control (2.83) could be due to the fact that the heat accelerated the Millard reaction and made the protein unavailable [19].

Moreover, usually much of the sulphur containing amino acids such as cystein and methionine supplied in the diet were used to synthesize pancreatic enzymes [20]. This exacerbated the deficiency of sulphur containing amino acid in legume seeds, were manifested as a lower production of body tissues.

The low PER value for cooked inclusive diets when compared with the control PER value which might be due to the fact that the heat treatments given to the seeds of Canavalia Plagiosperma were not effective to totally eliminate the anti-nutrients in the seed, which interferes with the protein quality of the seeds. According to Friedman [21], PER value below 1.5 describes a protein of poor quality; between 1.5 and 2.0 an intermediate quality and above 2.0 good quality proteins. Hence, 75:25 blends of cooked seed of C. Plagiosperma and control were considered as intermediate quality seed proteins; whereas 50:50, 25:75 blends of cooked seeds of C. Plagiosperma and the control respectively, as well as the control diet possess protein with good quality.

Effect of cooked (50 minutes) C. Plagiosperma seed on the Haematological Parameters of Albino rats

The effect of cooked (50 minutes) C. plagiosperma seed on the heamatological parameters of albino rats are presented in Table 3 .

Hematological parameters are important indices of the physiological and pathological status for both animals and humans [22]. It can also be used to determine the extent of deleterious effect of foreign compounds, including plant extracts, on the blood of the albino rats [2]. Heamatological parameters can also be used to explain blood relating functions of plant extract or its products $[2,23,24]$.

The cooked (50 minutes) Canavalia plagiosperma seed had a significant increasing effect $(\mathrm{p} \leq 0.05)$ on the Red blood cell (RBC), packed cell volume (PVC), Haemoglobin $(\mathrm{Hb})$ and mean corpuscular volume (MCV).This may be as result of some residual anti-nutrients present in the feed which must have affected the parameters. On the other hand, the result showed a significant decreasing effect $(\mathrm{P} \geq 0.05)$ in mean corpuscular haemoglobin concentration (MCHC) and mean corpuscular haemoglobin (MCH).

The mean corpuscular volume (MCV) and red blood cells (RBC) which are important in the diagnosis of anemic condition increased significantly in the feed mixes when compared with the control, though it is without a definite trend in its increment. While mean corpuscular haemoglobin concentration (MCHC) and mean corpuscular haemoglobin (MCH) which are also important in the diagnosis of anaemic conditions all decreased significantly $(\mathrm{p}<0.05)$. Mean corpuscular haemoglobin concentration (MCHC) decreased as the concentration of the cooked sample of Canavalia plagiosperma seed increased in the feed mix while mean corpuscular haemoglobin $(\mathrm{MCH})$ did not show any definite pattern of decrease as the sample concentration or ratio increased. Since red blood cell (RBC) indices are not as important as direct RBC observation, the four substances may still be said to have heamatinic effects.

Table 3. Effect of Cooked (50 minutes) C. Plagiosperma seed on the Haematological Parameters of Albino rats

\begin{tabular}{|c|c|c|c|c|c|c|c|}
\hline $\begin{array}{l}\text { Haematological } \\
\text { ParameterS }\end{array}$ & $\begin{array}{c}\text { Red Blood } \\
\text { Cells } \\
\left(\mathrm{x} 10^{6} / \mathrm{mm}^{3}\right)\end{array}$ & $\begin{array}{l}\text { Packed cell } \\
\text { volume (\%) }\end{array}$ & $\begin{array}{l}\text { Haemoglobin } \\
\text { (g/dl) }\end{array}$ & $\begin{array}{c}\text { Mean } \\
\text { corpuscular } \\
\text { volume (\%) }\end{array}$ & $\begin{array}{l}\text { Mean corpuscular } \\
\text { Haemoglobin (\%) }\end{array}$ & $\begin{array}{l}\text { Mean Corpuscular } \\
\text { Haemoglobin } \\
\text { Concentration (\%) }\end{array}$ & $\begin{array}{c}\text { Platelets } \\
\text { (X10/UL) }\end{array}$ \\
\hline Control group animals ${ }^{1}$ & $3.97^{\mathrm{d}}$ & $26.61^{b}$ & $8.43^{\mathrm{a}}$ & $74.17^{\mathrm{C}}$ & $21.31^{\mathrm{a}}$ & $28.43^{\mathrm{a}}$ & $1152.00^{a}$ \\
\hline Test group animals ${ }^{2}$ & $5.02^{c}$ & $29.71^{b}$ & $8.50^{\mathrm{a}}$ & $88.53^{b}$ & $17.10^{b}$ & $19.45^{b}$ & $590.33^{b}$ \\
\hline Test group animals ${ }^{3}$ & $5.19^{b}$ & $29.73^{b}$ & $8.57^{\mathrm{a}}$ & $89.23^{\mathrm{a}}$ & $16.73^{\mathrm{c}}$ & $19.17^{b}$ & $582.33^{d}$ \\
\hline Test group animals ${ }^{4}$ & $5.66^{\mathrm{a}}$ & $32.50^{\mathrm{a}}$ & $8.63^{a}$ & $89.43^{\mathrm{a}}$ & $15.45^{d}$ & $18.27^{\mathrm{c}}$ & $562.33^{d}$ \\
\hline LSD & 0.17 & 0.32 & 0.40 & 0.50 & 0.29 & 0.47 & 1.33 \\
\hline
\end{tabular}

NOTE: Means with different superscripts along the same column are significantly different at $\mathrm{p} \leq 0.05$,

LSD: Least significant difference

${ }^{1}$ Fed with $100 \%$ control

${ }^{2}$ Fed with $25^{* *}$

${ }^{3}$ Fed with $50 * *$

${ }^{4}$ Fed with $75 * *$

** \% Replacement with cooked sample. 
The packed cell volume (PCV), red blood cell (RBC) and haemoglobin concentration significantly increased $(\mathrm{p} \leq 0.05)$ as the sample (cooked seed) ratio/concentration was increased in the sample to feed mix that was given to the albino rats. These improved values of PCV, RBC and $\mathrm{Hb}$ indicate a haematinic and blood enhancer for the oblique-seeded jackbean seed. In other words, the rats did not suffer anaemia. This increase in PCV, Hb and RBC may possibly be as a result of the level of the ash content of the cooked sample of C. plagiosperma which indicates the amount of minerals present including iron ( $\mathrm{Fe}$ ) and Copper $(\mathrm{Cu})$ which are important in haemoglobin synthesis. The higher values of RBC and associated parameters are suggestive of polycythemia [25]. Therefore the cooked (50 minutes) seed may not have any adverse effect on the bone marrow, kidney and haemoglobin metabolism; since the value of RBC are not greatly affected [26].

The significant increase $(\mathrm{P} \leq 0.05)$ observed in packed cell volume (PCV) and haemoglobin as the concentration of the sample (C. plagiosperma seed) increased in the feed mix may have likely increased the values of these parameters (PCV and $\mathrm{Hb}$ ) beyond normal limits. A high haemoglobin level also suggests thromboembolism while high packed cell volume (PCV) beyond normal limits suggests venous thromboembolism/vascular accidents (heart failure/block, renal failure, Ishaemi stroke, possible retinopathy) $[15,27]$. Thus, it is likely that the mortality recorded may have resulted from the conditions mentioned above. Since the platelets decreased significantly $(\mathrm{p} \leq 0.05)$ as the sample (C. plagiosperma seed) concentration increased, there would be less risk of hyposplenism, myeloproliferative disorders or thrombocytosis, since these are caused by high level of platelets beyond normal level [15,27]. The deem, dull and partially closed eyes usually observed a day before the death of the albino rats were likely to be associated with this possible retinopathy mentioned above.

Differential counting of leucocytes in the blood of Albino rats feed different levels of cooked (50 minutes) Canavalia plagiosperma piper

The effect of cooked (50 minutes) C. plagiosperma seed on the Leukocyte count of albino rats are presented in Table 4. The differential count of Leucocytes in the blood of albino rats are reported to be affected by a range of factors, which include species, size, age, physiological status, environmental conditions and dietary regime, e.g. quality and quantity of food, dietary ingredients, protein sources, vitamins, probiotics [28]]. The cooked (50 minutes) Canavalia plagiosperma seed had a significant increasing effect $(\mathrm{p} \leq 0.05)$ on white blood cell $(\mathrm{WBC})$ and neutrophiles but did not produce any definite pattern (either continuous rise or fall) on lymphocytes and eosinophiles. This may be as result of some residual antinutrients present in the feed which must have affected the parameters.

The Neutrophiles and white blood cell showed a significant increase $(\mathrm{p} \leq 0.05)$ with increase in the cooked sample concentration in the feed mix while there was no significant difference $(\mathrm{P} \geq 0.05)$ for basophiles and monocytes. It showed no definite pattern of rise or fall for eosinophiles and lymphocytes. White blood cells (WBC) are important in defending the body against infection [29]. The white blood cell count however cannot give a definite or specific information but the result of a differential white blood cell count (Neutrophiles, eosinophiles, Monocyte, lymphocytes and Basophiles) narrows down to give specific information about infections, toxicity allergy and immuno-suppression and poisoning [29]. The function of lymphocytes is primarily its involvement in a variety of immunological functions, such as immunoglobulin production and modulation of immune defence [30]. The alteration in lymphocytes count reflects possible leukopoietic and immunodulatory effects of Canavalia plagiosperma seed. It is possible that Canavalia plagiosperma is composed of bioactive ingredients containing hematopoietin like principle which is responsible for hematopoietins synthesis or release from haematopoietic organs such as the kidney and liver [31].

Moreover, an elevation in lymphocytes at higher concentrations of Canavalia plagiosperma seed sample might be associated with chronic inflammation of liver and kidney of rats after being fed with the feed mixes. Eosinophiles are responsible for allergic reactions and disorders, It increases with allergic conditions and decreases with stress and/or infection [1,2,15]. Neutrophiles is mainly responsible for phagocytosis of pathogenic micro organism during the first few hours after their entry into tissues [1]. Monocytes are responsible for defense of tissues against microbial agents; It increases with bacterial infection and decreases with stress [15]. Basophiles counts increase upon sensitization to an antigen (or allergen).

Table 4. Differential counting of leucocytes in the blood of Albino rats fed different levels of Cooked (50 Minutes) Canavalia plagiosperma piper

\begin{tabular}{|c|c|c|c|c|c|c|}
\hline $\begin{array}{l}\text { Haematological } \\
\text { Parameters }\end{array}$ & $\begin{array}{c}\text { White blood cells } \\
\left(\mathrm{x} 10^{3} / \mathrm{mm}^{3}\right.\end{array}$ & $\begin{array}{c}\text { Monocytes } \\
(\%)\end{array}$ & $\begin{array}{c}\text { Lymphocytes } \\
(\%)\end{array}$ & $\begin{array}{c}\text { Eosinophiles } \\
(\%)\end{array}$ & $\begin{array}{c}\text { Basophiles } \\
(\%)\end{array}$ & $\begin{array}{c}\text { Neutrophiles } \\
(\%)\end{array}$ \\
\hline Control group animals ${ }^{1}$ & $1.45^{\mathrm{C}}$ & $00^{\mathrm{a}}$ & $86.63^{d}$ & $00^{\mathrm{a}}$ & $00^{\mathrm{a}}$ & $13.67^{\mathrm{c}}$ \\
\hline Test group animals ${ }^{2}$ & $2.90^{\mathrm{b}}$ & $00^{\mathrm{a}}$ & $93.17^{\mathrm{a}}$ & $00^{\mathrm{a}}$ & $00^{\mathrm{a}}$ & $20.33^{\mathrm{b}}$ \\
\hline Test group animal $^{3}$ & $3.20^{\text {ba }}$ & $00^{\mathrm{a}}$ & $87.30^{\mathrm{c}}$ & $00^{\mathrm{a}}$ & $00^{\mathrm{a}}$ & $26.67^{\mathrm{a}}$ \\
\hline Test group animal $^{4}$ & $3.39^{\mathrm{a}}$ & $00^{\mathrm{a}}$ & $90.10^{\mathrm{b}}$ & $00^{\mathrm{a}}$ & $00^{\mathrm{a}}$ & $27.67^{\mathrm{a}}$ \\
\hline LSD & 0.47 & 00 & 0.70 & 00 & 00 & 1.09 \\
\hline
\end{tabular}

NOTE: Means with different superscripts along the same column are significantly different at $\mathrm{p} \leq 0.05$,

LSD: Least significant difference

${ }^{1}$ Fed with $100 \%$ control

${ }^{2}$ Fed with $25 * *$

${ }^{3}$ Fed with $50 * *$

${ }^{4}$ Fed with $75 * *$

** \% Replacement with cooked sample. 


\section{Conclusion and Recommendations}

The results realized from the proximate composition of the diets indicated that the protein and carbohydrate content of the seed, when properly processed could be helpful in reducing nutritional related problems (such as protein-calorie malnutrition) in Africa, and the cooked Canavalia plagiosperma seed meal could be used as a substitute for protein in food formulations for man and livestock. The result of the haematology/toxicity study suggests that Canavalia plagiosperma piper has the potential of defending the body against infection and also has haematinic and blood enhancing quality.

Further study on chronic and histopathological toxicity study is recommended to be carried out so as to ascertain the effect of C. plagiosperma seed on the different organs of the albino rats

\section{References}

[1] Akinmutimi, A.H. (2004). Evaluation of Sword bean (Canavalia gladiata) as an alternative feed resources for broiler chickens. $\mathrm{PhD}$ Thesis Department of Non-ruminant animal production, Micheal Okpara University of Agriculture Umudike, Nigeria.

[2] Odeyemi, O.O., Yakubu, M.T., Masika, P.J. and Afolayan, A.J. (2009). Toxicological evaluation of the essential oil from Mentha Longifolia L Suosp. Capensis Leaves in rats. J. Med. Food (12(3): 669-674.

[3] Esonu, B.O., Anumni, P.E., Udedibie, A.B.I., Emenalom, O.O., Etuk, B., Odoemelam, V. and Okorie, K.C. (2013). Evaluation of Two- Stage cooked Canavalia plagiosperma (piper) seed meal as feed ingredient in layer Diets. Nigerian journal of Animal Science 15: 95-103.

[4] Moreina, R.A., Cordeiro, E.F., Cavada, B.S., Nunes, E.D., Fernerndes, A.G. and Oliveine, J.T.A. (1993). Plant Seed Lectins. A possible marker for Chemotaxonomy of the qenus Canavalia. R. Bras. Veg. Brazil. 127-132.

[5] Odoemelam, V.U. (2007). Proximate Composition, anti-nutritional properties and mineral assay of raw and processed Canavalia plagiosperma seed. M.Sc. Thesis, Department of Animal Production and Management, Micheal Okpara University of Agriculture, Umudike, Abia State, Nigeria.

[6] Esonu, B.O. (2009). Unconventional Feed resource for Livestock development and food security, paradigms from Nigerian livestock Industry. 14th Inaugural Lecture of Federal University of Technology, Owerri, Imo State, Nigeria. Delivered on Wednesday 24th of June, 2009.

[7] Udedibie, A.B.I., Esonu, B.O. and Agbabiaka, L.A. (2000). Comparative performance of broilers fed diets containing differentially processed Jack bean meals. NPSJ. I: 32-41.

[8] Alagbaoso, S.O., Nwosu, J.N., Agunwa, I.M.,Njoku, N.E., Akajiaku, L.O. and Eluchie, C.N. (2016). Effect of Some Thermal Processing Techniques on the Anti- nutritional Factors of Canavalia plagiosperma Piper Seeds. American Journal of Food Science and Technology. Vol. 4, No. 1, 7-13.

[9] A.O.A.C. (2000). Official methods of analysis 17th edn. Association of Official Analysis Chemist (A.O.A.C) International, Gaithersburg, M.D.

[10] Onuh, M.O. and Igwemma, A.A. (2000). Applied Statistical techniques for Business and Basic Sciences. Skillmark Media Ltd. Owerri, Imo State. Pp. 176-190, 205-215, 322-338.

[11] Aruah, B.C, Uguru, M.I, and Oyiga, B.C (2012). Genetic variability and interrelationship among some Nigerian pumpkin accessions (Curcurbitassp). Plant Breeding. Int. J. (6): 34-41.

[12] Enwereuzoh, R.O., Okafor, D.C., Uzoukwu, A.E., Ukanwoke, M.O., Nwakaudu, A.A and Uyanwa, C.N (2015). Flavour extraction from Monodora myristica and Tetrapleura tetraptera and production of flavoured popcorn from the extract. European Journal of Food Science and Technology. Vol.3, no 2, 1.17.

[13] Alagbaoso, S.O., Nwosu, J.N., Njoku, N.E., Ojukwu, M., Okafor, D.C. and Eluchie, C.N. (2015). Growth performance and haematology of albino rats fed varying inclusions of autoclaved canavalia plagiosperma piper seed meal based-diets. American Journal Of Food And Nutrition (AJFN). 5(2): 35-48.

[14] Effiong, G.S., Ibia, I.O. and Udofia, U.S (2009). Nutritive and energy values of some wild fruit spices in Southeastern Nigeria. Electronic Journal of Environment, Agriculture and food chemistry. 8(10); 917-923.

[15] Lewis, S.M., Bain, J.B. and Bates, I. (2006). Practical Haematology (10th ed.) Elsevier Ltd, Sriniwaspuri, New Delhi, India. Pp. 29-58, 131-160, 609-624.

[16] Gupta, V., Modgil, R. and Kalia, M. (2005). Effect of domestic processing on the Invivo protein quality of faba bean (Vicia faba).Journal of Food Science and Technology 42, 501-503.

[17] Saharan, K. and Khetarpaul, N. (1994). Protein quality traits of vegetable and field peas: Varietal differences. Plant Foods for Human Nutrition 45, 11-22.

[18] Pugalenthi, M., Vadivel, V. and Janak, P. (2007). Comparative evaluation of protein quality of raw and differentially processed seeds of an underutilized food legumes, (Abrus precatorius L) livestock Research for Rural Development Article No. 168. Available in the online website. http://www.lrrd.Org/lrrd19/11/puga19168.htm.

[19] Sagarbieri, U.C. (1989). Composition and nutritive value of beans (Phaseolus vulgaris L.) W/d Review in Nutrition and Dietetics 60, 132-186.

[20] Fernandez, M., Lopez-Jurado, M., Aranda, P. and Urbano, G. (1996). Nutritional assessment of raw and processed faba bean (Vicia faba l) Cultivar Major in growing rats. Journal of Agricultural and Food Chemistry 44, 2766-2772.

[21] Friedman, M. (1996). Nutritional value of proteins from different food sources. A review: Journal of Agricultural and Food Chemistry 44, 6-29.

[22] Adeneye, A.A., Ajagbonna, O.P. and Bello, S.O. (2006) Preliminary toxicity and Phytochemical studies of the stem bark aqueous extract of musanga cecropioides in rats. Journal of Ethnopharmacology 105(3): 373-379.

[23] Ajayi, I.A., Oderinde, R.A., Ogunkoya, B.O., Egunyomi, A. and Taiwo, V.O (2005). Chemical Analysis and Preliminary toxicological evaluation of Garcinia Mangostana seeds and seed oil. Food and Chemical Toxicology 32: 999-1014.

[24] Akinnawo, O.O., Abatam, M.O. and Ketiku, A.O. (2002). Toxicological study on the edible larva of Cirina forda (west wood). African Journal of Biomedical Research 5: 43-46.

[25] American Diabetes Association, (2000). Nutrition Recommendation and Principles for Diabetes mellitus, Clinical Practice recommendations. Diabetes Care 23: 543-546.

[26] Young, N. S. and Mecie-Jewski. (1997). The path physiology of Acquired A Plastic anemia. New Eng. Journal of Medicine 336; 1365.

[27] Hoffbrand, A.V., Pettit, J.E., and Moss, P.A.H. (2004). Essential Haematology (4th ed.) Blackwell Science Ltd, Massach-Usetts, USA.

[28] Osigwe, D.C., Obiekezie, A.I. and Onuoha, G.C. (2005). Some haematological changes in hybrid catfish (Heterobranchus longifilis X Clarias gariepinus) fed different dietary levels of raw and boiled jackbean(Canavalia ensiiformiis) seed meal. African journal of Biotechnology 4; 1017-1021.

[29] Aboderin, F.I. and Oyetayo, V.O. (2006). Haematological Studies of rats fed different doses of probiotic, Lactobacillus Plantarum, Isolated from fermenting Corn Slurry. Pakistan Journal of Nutrition 5(2): 102-105.

[30] Campbell, T.W. (1996). Clinical Pathology In: Mader DR (ed) Reptile Medicine and Surgery. WB Saunders Company, Philadelphia, PA, U.S.A. Pp 248-257.

[31] Palani, S., Senthilkumar, B., Praveen, R., Kumar, P., Devi, K., Venkatesan, D. and Sathendra, E.R. (2009). Effect of the ethanolic extract of indigofera barberi (L) in acute acetaminophen Induced nephrotoxic rats. Advanced Biotechnlogy 25: 28-31. 